日本臨床麻酔学会第 26 回大会パネルディスカッション

女性麻酔科医だからできること

患者に優しい緩和医療

合田由紀子*

\begin{abstract}
[要旨]「女性麻酔科医は緩和医療に向いている」ということを, 自身の体験を通じて 明らかにした．緩和ヶアの領域において麻酔科医は疼痛治療のスペシャリストとして 大きく期待されており，特に緩和ヶア病棟医よりも緩和ヶアチームを担う緩和ケア医 にふさわしい，なかでも女性麻酔科医はチーム医療において協調し協働すること，患 者・家族の話を聴き, 気持ちを理解すること, 生活に配慮した治療法を工夫すること などにおいて，男性に優る力を発揮できる．麻酔科のサブスペシャルティに緩和医療 を位置づけ，緩和ケアチームに専従または専任医師を送る体制をつくることにより， 麻酔科および緩和医療が相互に発展できる仕組みづくりは十分可能である. キーワード：緩和ケア，女性医師，麻酔科医
\end{abstract}

（日臨麻会誌 Vol.28 No.2, $281 ２ 88,2008$ )

\section{はじめに}

パネリストとしてこのタイトルをいただいたと き，私はなんとなく違和感を覚えた。「女性医師だ から」とくれば「……いって甘えてはいけない」 式の思考パターンが私の潜在意識にあり，仕事のう えでは女性であることを肯定してはこなかった自分 がいたからである。パネルの準備過程で司会者や他 のパネリストの先生方と意見交換するなかで，「女 性医師だからできる……と自分自身の仕事を肯定 的に振り返ってみると, なんだか嬉しくなり, 元気 が出てきて前向きな気持ちになれることに気づい た。そしてそのことをパネルディスカッションで発 表する機会をいただくとは，なんと光栄なことかと 思うようになった。この場で私が述べたいことは，前
の 5 人の司会者およびパネリストたちの「女性医師は 麻酔科医に向いている」という論旨を受けて ${ }^{1) \sim 5)}$, さらに「女性麻酔科医は緩和医療に向いている」と いうことを，自身の体験を通じて明らかにすること である.

\section{I＼cjkstart市立札幌病院緩和ケアチームの活動}

まず，私の現在の仕事を紹介したい.

市立札幌病院では 2004 年 10 月に緩和ケアチーム を立ち上げ，私は身体症状コントロールの専従医師 として 2 年半活動してきた。緩和ケアチーム活動は, 主治医より依頼のあった入院患者について症状コン トロールや精神面のケア, 療養の場のサポートなど をチームとして提供するものである。当院には緩和 ケア病棟はないので，この緩和ケアチームが緩和ケ
著者連絡先 合田由紀子

于 060-8604 札棍市中央区北11条西 13丁目 1-1 市立札幌病院緩和ケア科 
アの主たる担い手となっている，また，緩和ケア病 棟で提供される緩和ケアと異なるところは, がんの 積極的治療の段階からかかわることが多いという点 である。

体制は，身体症状コントロール医師が専従 1 名， 専任 1 名, 精神症状コントロール医師が専任 1 名, ホスピスケア認定看護師の専従 1 名がコアメンバー として活動している。チーム連携している専門部署 は, 薬剤部, 栄養科, リハビリテーション科, 看護 相談室, 口腔ケアチーム, がん化学療法看護認定看 護師，皮膚・排泄ケア認定看護師，ボランティアの 会などで，それぞれの代表者と患者を依頼した主科 の担当医が週に 1 回の緩和ケアチームカンファレン スに参加して情報交換し, 患者のニーズに応じて協 働している。専従メンバーは, 毎日病棟ラウンドを して痛みをはじめとした諸症状のコントロールのた め直接的診療を行ったり，コンサルテーションに応 じたりしている。また主治医による病状や治療の選 択時等の説明の場に同席して, 患者がよく理解した うえで自己決定できるようにサポートしている，在 宅移行時は，地域医療と連携するための合同カンフ アレンス等にも参加し, 患者や家族が安心して在宅 療養できるようにサポートしている。退院患者の外 来診療(週 2 日, 半日ずつ)も行い, 在宅における症 状コントロールが継続して行えるようにしている。

教育・啓蒙活動としては定期的学習会・講演会の 開催, 医学生, 看護学生の講義, 院内用の疼痛治療 マニュアルや患者向けパンフレット等の作成などを 行い，地域連携としては地域ホスピス・緩和ケア・ 在宅ケアネットワークへの参加・協㗢などを行って いる.

活動実績として，2006年度の新規依頼件数は 203 件, 月平均 17 件, 実人数は 148 名 (2回以上の入院も あるため), 平均介入日数 30 日, 在院死 90 名 (実人数 の $60 \%$ ) だった (表 1)。依頼内容の $90 \%$ 以上が疼痛 コントロールで, ほかに倦急感・呼吸困難感・嘔気 など複数症状のある例が多く, せん妄やうつ等の精

\section{表 1 緩和ケアチームの活動実績}

\begin{tabular}{lcc}
\hline & 2005 年度 & 2006 年度 \\
\hline 年間件数 & 202 件 & 216 件 \\
新規依頼 & 182 件 & 203 件 \\
月平均 & 15 件 & 16.9 件 \\
新規実人数 & 139 人 & 148 人 \\
在院死 & 88 人 (63\%) & 90 人 $(60 \%)$ \\
平均介入日数 & 33 日 & 30 日 \\
\hline
\end{tabular}

\section{表 2 依頼の主訴(重複あり, 2005 年度)}

\begin{tabular}{lr}
\hline 疼痛 & 175 件 $(96 \%)$ \\
食欲不振 & 21 件 $(12 \%)$ \\
倦急感 & 20 件 $(11 \%)$ \\
腹部膨満感 & 19 件 $(10 \%)$ \\
呼吸困難感 & 10 件 $(5 \%)$ \\
嘔気 & 10 件 $(5 \%)$ \\
嚥下困難 & 5 件 $(3 \%)$ \\
不安 & 3 件 $(2 \%)$ \\
咳 & 2 件 $(1 \%)$ \\
\hline
\end{tabular}

神症状のコンサルテーションも増加している(表2). また療養先の相談依頼なども受けている.

\section{II 緩和医療への契機}

私が緩和医療に取り組み始めた契機を振り返って みると，いくつかの場面が浮かんでくるが，そのう ち最も印象深い事柄は 15 年ほど前にさかのぼる. 全館当直をしていた夜中にある病棟に呼ばれ，主治 医が到着するまでのいわば「つなぎ役」としてがん 患者の臨終に立ち会った。初対面のその患者は長い こと痛みに苛まれてきた様子で, 最期の一呼吸まで 呻き声を上げながら命を閉じた。私はその呻き声の 激しさに呆然と立ちすくむばかりだった。傍らでは 娘さん(らしき人)が「ごめんね，ごめんね。せ女て 痛みだけでもとってあげられたら……と泣きくず れていた。あやまるべきは「痛みの専門医」である はずのこの私ではないか，私はいったい何をしてい たのだろうと恥じ入る思いであった。それまでの私 は術前後の回診以外は手術室にこもりきりの麻酔科 医で，多くのがん患者が病棟で痛みに苦しんでいる 
ことすら知らなかったのである.

ちょうどその当時，敬愛する先輩の佐々木和郎先 生が北海道がんセンターで緩和医療にいち早く取り 組んでおられたので，その教えを請いながら私も遅 まきながら癌性疼痛治療に取り組み始めたのだが, まもなく壁に突き当たってしまった。当時はがんの 痛みに苦しみ，余命わずかの患者に対して，まず何 と言葉をかけたらいいのかもわからず立ち往生して しまったのである。「がん患者さんへの全人的かか わりについて研修したい」という私の希望を，佐々 木先生が友人の国立がんセンター中央病院麻酔科部 長に伝えてくださり，その勧めで設立 1 年目の国立 がんセンター東病院緩和ケア病棟で研修する機会に 恵まれたのである. 3 カ月という短い期間ではあっ たが，この研修のなかで緩和医療こそ自分のライフ ワークにほかならないと感じたのであった。しかし ながら，まさに研修の成果を地元での実践に生かそ うとしていた矢先に，佐々木先生が胃癌で夭逝され てしまった. 大きな悲しみと喪失感を抱きながらも， 先輩の遺志を受け継いで自分なりに細々と緩和医療 を担ってきた。

緩和ケアチームの専従医師となるまでは, 麻酔科 医として手術麻酔管理とペインクリニック外来, そ して癌性疼痛治療の業務に携わりながら, 緩和医療 に十分に時間をかけられないもどかしさも抱いてき た。しかし，緩和ケア専従となった今日では 27 年 間にわたって培った麻酔科医としての専門性は緩和 医療に大いに役立つと再確認しながら仕事を行って いる。また振り返れば，緩和医療を担うようになっ てからの手術麻酔管理は, 術後鎮痛も術後嘔気対策 も怠りないものにしょうと，よりきめ細かく心配り するようになっていった。

\section{III＼cjkstart緩和ヶアは私のライフワーク}

緩和ケアをライフワークと感じたところは何かと いうと，一つには麻酔科医として麻酔管理を行った 患者が手術室を出て行った「その後」が，歳を重ね
るにつれて気にかかるようになったことである。が んの根治手術が行われても再発もありうるし，姑息 手術も手術不能例もある。治癒手術ができたとして も，術後は無事に回復できたのだろうか？患者に とってがんとの長い闘病年月のうちで, 麻酔科医の かかわる時間はほとんど点でしかないということに 物足りなさを感じ始めていた。

また，13年前にはまだ，死は医療の敗北という意 識が医師のなかに広くあり, 医療の現場で死に逝く 人が大切にされていないのではないかという疑問を 抱くことも少なからずあった。手術室でも，時には 重篤な患者の意思が確認されないまま繰り返される 緊急再手術, 再々手術の麻酔管理を担うこともあり, これは患者自身が望んでいる医療なのだろうかとい う疑問を深めていった。穏やかで安らかな死を受容 することができない原因は医師の意識の側にも大き な要因があるのではないかと思う場面もあった。

そのような問題意識を抱いていた私にとって，䋸 和ケア病棟での研修はカルチャーショックを伴いな がらも確かな回答を与えてくれた。「生きることを 尊重し, 誰にも例外なく訪れる『死に行く過程』に も敬意を払う」というWHOの緩和ケアの実践目標 のなかに，自分の担いたい医療の原点を見つけた思 いがした(表3)。

\section{IV 自分の看取り体験から}

身近な人の看取り体験から私が得たことを紹介し たい.

10 年前, 本州の実家の父は呼吸不全で入院して 16 日目に他界したが，最期の呼吸困難感という苦痛 に対して，私から主治医に頼んでもモルヒネを十分 には使ってもらえなかった，父が精査を拒んでいた ので原因不明であったからかもしれないが，「モル ヒネは最期の危険な薬」という考えがその病院では まだ一般的だったのだろうと思う。主治医は休日も 診察し多忙ななかで誠意をこめて診療してはくれた が，「モルヒネは院内に主治医がいるときに限り使 
表3 麻酔科医から緩和ケア医(ライフワーク)へ

手術患者の「その後」が気になっていた

「死を敗北」としか認めない医療への疑問…

患者の意思が不明な緊急再手術，再々手術への疑問…

穏やかで安らかな死のために支援できないか

$\downarrow$

「生きることを尊重し, 誰にも例外なく訪れる『死に行く過程』にも

敬意を払う」緩和ヶア $\rightarrow$ 自分の担いたい医療の原点を見つけた

用可能」という縛りのある指示だったのである. そ れでもモルヒネ $5 \mathrm{mg}$ を静注してもらうと, 呼吸促迫 状態で胸をかきむしっていた父の呼吸がゆっくりと 深々とした形に変わり，すやすやと眠り出すのをつ ぶさに観察できた。 84 歳で初めてモルヒネを使うと いうのに，呼吸抑制を生じるどころか，激しい呼吸 困難をかくも安らかに緩和するのかとその威力に改 めて感動した。しかしこのモルヒネも 1 日 2 回程度 しか使ってはもらえず，効果が切机て再び苦しみだ す父のベッドサイドでなすすべもなく, 他院では自 分には診療権がないことの悔しさに涙が出た。この ときに，たとえ数日あるいは数時間の短い時間でも， 最期の苦しみが緩和されないときに家族が味わう辛 さや無力感を思い知らされた。 今振り返れば,「最 期の瞬間まで苦痛の緩和を怠るな」という父から私 へのメッセージだったのかとも思える。

同居していた義父は 6 年前に食道癌で他界した が，訪問看護を頼み本人の希望どおりに在宅で最期 を迎えることができた。義父は嬹下困難になっても 点滴は束縛感があるのと, 尿意が生じて負担だと言 って断り，尿道留置カテーテルも最期まできっぱり と拒んだ。孫たちも含めて家族でローテーションを 組んで添い寝をし, 皆で順に死に水を取り, 本人の 思いどおりにしてあげることができて穏やかな良い 最期だったと思う。1本の管も入らず，むくみもな く，きれいなままの遺体であった。このように義父 が自ら選んだ最期の在り様は, 先に逝くものとして の手本を家族に示してくれたように思えるのであ
表4 女性医師は緩和医療に向いているか？

患者の気持ちを理解するカ

コミュニケーションするカ

協調し協働する力

看護師の話を聞くカ

生活に配慮した治療方法を考える力

繰り返しベッドサイドに訪問し続けるカ

細かい対応を厭わない力

*女性はこれらのカを優位にもっている

る、私の緩和ケアの体験がいくらか役立ち, 義父の 望みを叶えることができたという充足感も，義父か らの心に残る贈り物である。

\section{$\mathrm{V}$ 女性医師は緩和医療に向いているか？}

緩和ケアの対象とする患者の多くは人生の最終章 を生きているので，そこにかかわる緩和ケア医自身 が喜びも悲しみも含めたさまざまな生活体験をもつ ているほど，患者を深く理解し共感することができ るであろう。

ほかのパネリスト達が提示した「女性医師は麻酔 科医に向いている」1) 5) といういくつかの利点は緩 和ケアにおいてはいっそう有効なものとなる。患者 の気持ちを理解する力, コミュニケーションする力, 協調し協㗢する力，看護師の話を聞く力，自分の生 活体験を基に患者の生活に配慮した治療方法を考え る力，繰り返しベッドサイドに訪問し続ける力，細 かい対応を厭わない力など，緩和ケアにとりわけ必 要な能力は女性の方が優位といえるだろう(表 4). 
表 5 麻酔科医は緩和医療(緩和ケアチーム医)に向いているか?

・痛み治療のスペシャリスト

身体症状コントロールの9割以上は疼痛対策

痛みの診断，評価ができる

・麻酔管理でケアマインドを育んでいる

・麻酔管理で臨床薬理を習得している

オピオイド，鎮痛補助薬，制吐薬，鎮静薬等に習熟している

・多数の科とのコミュニケーション能力を磨いている

・術前後の病棟ラウンドは緩和ヶアチームのラウンドに似ている

・執刀医(主治医)をサポートする能力を磨いている

もちろん男性にもこれらの能力に優れた人もいる が，どちらかといえばスキルフルな個人技を磨く方 がいいという夕イプが多いのではないか.これらの 違いは，女性の多くが家族を含む社会生活のなかで 後天的に獲得した特質であるとは思うが，そ扎だけ ではなく人間という種が長い歴史のなかで，女性と 男性の根源的役割分担を遺伝子に刷り込んできたこ とに由来するのではないかと私は思っている.

\section{$\mathrm{VI}$ 麻酔科医は緩和医療に向いているか？}

この議論はすでに日本臨床麻酔学会第 24 回大会 のシンポジウム「麻酔科医の緩和ケアを語ろう」で も行われているが，私もそこでのシンポジストたち の考元にほぼ同感である ${ }^{6), 7)}$ ，麻酔科医は緩和ケア 病棟よりも緩和ケアチームの緩和ケア医として活躍 しやすいと思う。緩和ケア病棟の緩和ケア医は end -of-life careを受け持ち医として行わなければなら ない，麻酔管理を主な仕事としてきた麻醉科医は一 般に受け持ち医としての経験が少ないので，この敷 居は高いと思わ机る。他方，緩和ケアチームには抗 がん治療中の患者も多く依頼され，治療に伴う疼痛 に対しても機敏に静脈麻酔で対応するなど, 麻醉管 理技術を応用して対応する場面も多い.

緩和ケアチームの緩和ケア医として麻酔科医が有

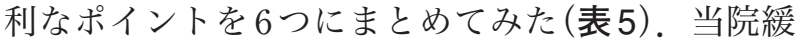
和ケアチームへの依頼内容の $90 \%$ 以上が疼痛コン トロールであることからも, 「疼痛治療のスペシャ
リスト」である麻酔科医は大いに力を発揮できるこ とがまず第1のポイントである，疼痛治療のスペシ ヤリストとは必ずしも神経ブロック技術の巧みなぺ インクリニシャンを指すだけではなく，手術麻酔管 理を行うなかで磨かれるものと考元ている。なぜな らば手術侵襲こそ最強の疼痛刺激であり，その侵襲 から患者を守るために技術を磨き，ケアマインドを 日々育くんでいるのだから ${ }^{8)}$ 。また，この麻酔科医 のケアマインドは緩和ケアに生かすことのできる第 2 の大きなポイントである。麻酔科医と緩和ケア医 に共通するケアマインドを相互に生かし合うこと は，両者の発展に寄与するものと思う。麻醉科医は オピオイド，鎮痛補助薬，制吐薬，鎮静薬などに関 する臨床薬理に習熟しており，これを緩和ケアに活 用できることが第 3 のポイントである ${ }^{9}$ ．薬剤の静 脈内投与による経時的変化について麻酔科医は患者 に張り付いて観察しており，麻酔科医なら当たり前 に思うこのような薬に対する習熟度の深さはほかの 科では得られないものである。もちろん緩和ケアに おいては，対象は衰弱したがん患者であることに配 慮し，きめ細かい夕イトレーション法を身につけな くてはならない。そしてこのタイトレーション法は 緩和ケアから麻酔管理の場へ，その質を高放向 にフィードバックすることもできる.

麻醉科医はまた，中央部門である手術部において 多数の外科系の医師とコミュニケーションをとり， 多職種によるチーム医療のコーディネーターとして 


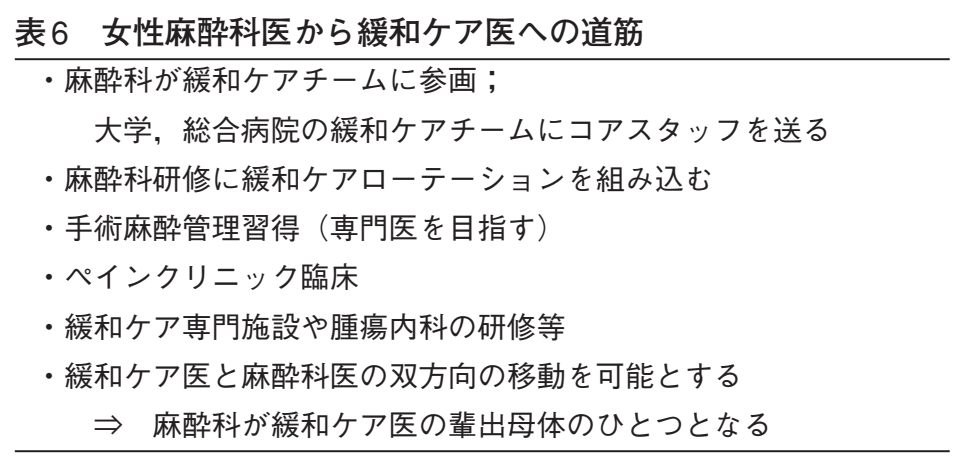

働いている点が第 4 に有利なポイントである. 術前 術後の病棟ラウンドでは多数の科を回るが，これは 緩和ケアチームの病棟ラウンドと似ており，このよ うな活動スタイルになじんでいる点も第 5 のポイン トにあげられる。また，麻酔科医の役割は患者をケ アするだけではなく外科医が手術に専念できる良い 環境を提供してサポートすることにもある。緩和ケ ア医は患者一主治医関係をサポートする立場でかか わることが重要で，麻酔科医が日常的に「サポート 力」を磨いていることは第6の有利なポイントとな る。このサポートカを上下, 軽重, 主従というょう にランク付けするのは間違っている. 楕円の中心が 二つあるように，両方がなくてはならない関係なの である。

以上のように麻酔科医のもつ有利な点を考える と, 麻酔科関連の学会レベルで緩和ケアを subspecialtyとしてしっかりと位置づける必要があると思 う。がん診療連携拠点病院をはじめとしてがん医療 を行う一般病院のほとんどには麻酔科が存在してお り，これからは緩和ケアチーム設置が必須となって いく時代の波を考えると, 麻酔科医を緩和ケアチー ムに専従あるいは兼任医師として参加させてイニシ アティブをとっていくことにただちに着手すべきで あろう。また subspecialty は相互にメリットをもた らし合う関係でなければならないとされるが，緩和 ケアの理念や技術は，麻酔およびペインクリニック や救急・ICUなどとの間にさまざまなメリットを交 換し合えるものである ${ }^{7}$.

\section{VII 女性麻酔科医の緩和医療への進出を期待して}

2002年には，一定の施設基準を満たしている「緩 和ケアチーム」に診療報酬が認められ，2007年4月 からは「がん対策基本法」が施行されて，「全国ど こでも専門的がん医療の提供と同時に，早期から適 切な緩和ケアが行われるように，その質的水準を均 填化していく」という政策が推し進められようとし ている．緩和ケアに携わる者にとつては行政が後押 しする好機が訪れたように思えるが，事態は甘くは ないと感じている。今後の日本はかつてない高齢化 社会を迎えると同時に，がん患者の急速な増加は避 けられない。適切ながん医療を推し進めるうえで, 高齢がん患者に対する緩和ケアの比重は大きくな り，それを担うマンパワーが求められるだろう。医 学教育にも緩和医療が位置づけられて医学生，なか でも女子医学生の関心の高まりが予測される。がん 患者とその家族はいつか訪れる死を想い予期的悲嘆 を体験するが，女性医師は自身の生活体験から，患 者の妻として，あるいは子をもつ親として，あるい は親を介護する娘として，時には嫁の立場で，その 悲嘆に共感できるだろう。そしてがんと共に生きる 患者の生活に配慮した治療法や療養形態を工夫する ことができると思う。また，緩和ケア医として体験 したことを自身の家族介護などに生かすこともでき るであろう。一般に女性は男性より生活意識が強い からである.

女性医師が緩和ケア医に至る道筋として, 研修過 
程では緩和ケア(チーム)研修もローテーションに組 み込み，そして専門分野としては麻酔科を入口とし て手術麻酔管理を十分に学び，さらにペインクリニ ックで痛みの診断や基礎的神経ブロックの技術を身 につけ，その過程で緩和ケアの他施設研修や腫瘍内 科の研修等を組み込み，これら数年の研修を経て希 望があれば緩和ケア専従医を選択できること，また 一定期間を経て希望があれば麻酔科医に戻ることも 可能であるような流動性のあるコースを麻酔科のな かにつくることが望ましいと思う(表6)。近年麻酔 科医の不足が深刻な問題ではあるが，この打開のた めに手術麻酔に特化した麻酔科医をつくろうとする ことは効果的ではない. 麻酔科が積極的に緩和ケア 医の輩出母体となることにより, 麻酔科学そのもの が広がりと魅力を獲得できると思う。

\section{まとめ}

今後求められる緩和ケアチームの緩和ケア医とし て麻酔科医の活躍が期待される。疼痛治療のスペシ ヤリストとしての自負は緩和ケア医としてのモチべ ーションを高めるものである.さらに女性医師は一 生活者としての体験を緩和ケアに生かすことがで き,また緩和ケアの体験を自身の介護などに生かせ るなど，仕事と私的生活をスパイラルに向上させる
こともできるであろう。

将来は緩和医療を専門に担いたいと思う多くの新 人女性医師がそのステップとして麻酔科の門戸を吒 いてくれることを，あるいはすでに麻酔科医である 女性医師たちが積極的に緩和医療の領域にも進出し 活躍してくれることを願っている.

\section{参考文献}

1）御村光子：「女性麻酔科医だからできること」によせ て. 日臨麻会誌 $28 ： 247-251,2008$

2）中村久美：患者に優しいインフォームドコンセント一 育児, 介護, 看取りの経験を生かそう一。 日臨麻会誌 $28: 252-258,2008$

3）中江文：麻配科医として体験した 3 度の帝王切開. 日臨 麻会誌 $28 ： 259-265,2008$

4）小澤章子：過去 2 回の手術体験からの安全で快適な婦人 科手術の麻酔管理. 日臨麻会誌 $28 ： 266-272,2008$

5）間宮敬子：患者に優しい小児麻酔。日臨麻会誌 28 ： 273-280, 2008

6）下山直人：麻酔科医がペインクリニシャン，そして緩 和ケア医となって。臨麻会誌 $26: 18-24,2006$

7）冨安志郎, 北條美能留, 中根秀之ほか：緩和ケアチー ムの立ち上げと麻酔科医。日臨麻会誌 $26 ： 25-33$, 2006

8）畑埜義雄：いま, 求められるケアマインド. 臨麻 29 ： 711-717, 2005

9）益田律子：緩和医療・ペインクリニック領域に扔ける オピオイド．日臨麻会誌 $26 ： 646-653,2006$ 


\title{
Female Anesthesiologists are Suitable for Palliative Medicine
}

\author{
Yukiko GODA \\ Department of Palliative Care, Sapporo City General Hospital
}

I have proved through my experience that female anesthesiologists are appropriate for palliative care. Anesthesiologists are expected to play a greater role as the doctor of the palliative care team than as the doctor of palliative care units in the management of cancer pain. Female anesthesiologists in particular are more suitable in the activities of cooperating with other team members, listening to patients and their families, empathizing with them, and paying attention to their daily lives than male anesthesiologists. Palliative care must be an important part of the activities of anesthesiologists, and anesthesiologists should be the principal member of the palliative care team. Palliative care will be able to expand the activities of anesthesiologists.

Key Words : Palliative care, Female doctors, Anesthesiologists

The Journal of Japan Society for Clinical Anesthesia Vol.28 No.2, 2008 